\title{
Redefining religion? A critical Christian reflection on CRL Rights Commission's proposal to regulate religion in South Africa
}

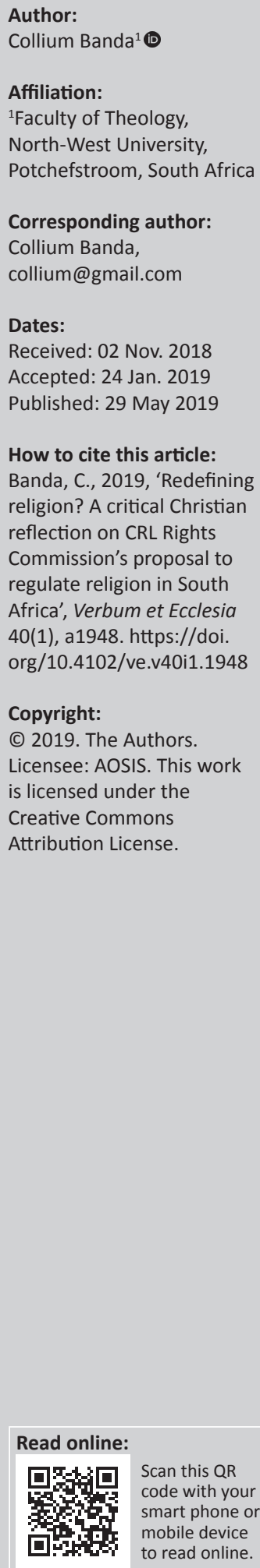

What do the recommendations of the Commission for the Promotion and Protection of the Rights of Cultural, Religious and Linguistic Communities (CRL Rights Commission) to regulate religion in South Africa reflect about the commission's understanding of religion in the country? From a Christian theological perspective, the article critically engages the understanding of religion that emerges from the findings and recommendations of the CRL Rights Commission on the state of religion in South Africa as contained in its 2017 report. The article first examines the different responses to the CRL Rights Commission's recommendations by writers concerned with freedom of religion and human rights in South Africa. Further, the commission's investigations, findings and recommendations are critically examined. This is followed by deciphering attitudes towards religion that emerge from the commission's recommendation for the regulation of religion in South Africa. The article closes by highlighting some possible dangers of regulating religion in a context riddled by economic inequality such as in South Africa.

Intradisciplinary and/or interdisciplinary implications: This article brings into dialogue Christian theology, religious freedom, human rights and the constitution, philosophy and sociology of religion to reflect on the essence of religion and freedom of religion in the context of undesirable and dangerous religious practices.

Keywords: CRL Rights Commission; freedom of religion; regulating religion; religion and state; religion and constitution; religious freedom in South Africa.

\section{Background and introduction}

The 2017 report of the Commission for the Promotion and Protection of the Rights of Cultural, Religious and Linguistic Communities (CRL Rights Commission) on the state of religion in South Africa has created palpable consternation within the Christian community. The commission's findings and recommendations are contained in its Report of the Hearings on the Commercialisation of Religion and Abuse of People's Belief Systems (2017). The commission recommended the regulation of religious communities in South Africa to curb 'the commercialisation of religion and the abuse of people's belief systems' after carrying out its 'extensive investigation' or 'investigative study' (CRL Rights Commission 2017:4, 6). The investigation was conducted in response to media reports of controversial activities in some Charismatic and Pentecostal churches in South Africa (CRL Rights Commission 2017:6).

The CRL Rights Commission is one of the six Chapter 9 institutions, designated as 'state institutions supporting constitutional democracy' (SA Constitution 1996:92). ${ }^{1}$ The commission is a constitutional arm of the state, operates outside government and partisan politics, and is free from interference from other state organs (CRL Rights Commission 2017:7). The Promotion and Protection of the Rights of Cultural, Religious and Linguistic Communities Act no. 19 of 2002 (CRL Act) states that the commissioners are appointed by the president of South Africa through a public nomination process administered by the Department of Traditional Affairs. The mandate of the commission is supporting constitutional democracy by promoting and protecting the cultural, religious and linguistic rights of communities. Subsection 1 of Section 185 of the constitution lists the primary objectives of the CRL Rights Commission:

(a) to promote respect for the rights of cultural, religious and linguistic communities;

(b) to promote and develop peace, friendship, humanity, tolerance and national unity among cultural, religious and linguistic communities, on the basis of equality, non-discrimination and free association; and

1.The other five institutions are the Public Protector, the South African Human Rights Commission, the Commission for Gender Equality the Auditor-General and the Electoral Commission. 
(c) to recommend the establishment or recognition, in accordance with national legislation, of a cultural or other council or councils for a community or communities in South Africa.

This means that the CRL Rights Commission's mandate is to ensure that the country's citizens enjoy their democratic right to religion, culture and language (CRL Rights Commission 2017:7). While the commission's primary mandate seems limited to promoting, protecting, monitoring, regulating and recommending rather than enforcing, it has shown itself as a powerful body, visibly active and vocal on cultural and religious issues in South Africa. Some of the high profile issues dealt with by the commission include religious extremism (Mabuza 2018), the sexual abuse of girls and women by religious leaders (Daniel 2018) and the death of boys in initiation schools (Collison 2017). The commission has in various ways sought to bring religious and cultural groups to account to the constitution of South Africa.

Consequently, in pursuit of its constitutional mandate, the CRL Rights Commission conducted a series of investigative hearings on the commercialisation of religion and abuse of people's belief systems in South Africa. While some religious people welcomed the commission's recommendations, many Christians expressed serious concern that the recommendations, if implemented, would erode freedom of religion and cede the church to state control. To some Christian objectors the idea of regulating religion signals the imminent end of religious freedom, the arrival of the antiChrist and religious persecution in South Africa.

The main question of the article can be stated as follows: what do the recommendations for the regulation of religion in South Africa by the CRL Rights Commission reflect about the commission's understanding of religion in the country? Answering this question leads to establishing the philosophical basis of the commission's proposals. Another pertinent emerging question is concerned with what it is that the commission seeks to regulate - is it beliefs or expressions thereof? This question is answered within the article's chief concern with the very notion of attempting to regulate religion, whether its beliefs or its expressions. However, in the South African context, where religion is important to many poor people, a further relevant question that needs to be asked and dealt with is the following: in a context riddled with high economic inequality and powerlessness, where many poor and powerless people rely on religion as a means of engaging their socio-economic and political reality, what would be the implications of regulating religion? This question centres on the likely impact of the commission's proposal for the regulation of religion in an African context, where religion traditionally 'permeates all the departs of life' (Mbiti 1969:2), has 'high utility value' (Nyathi 2001:6) and functions as a means of 'deal-making' (Kwenda, in Browning 2013) with the spiritual powers. Although presented with reference to the Christian community, the raised insights can benefit other religious groups in safeguarding their religious freedom. Furthermore, while the commission's report did raise some grave concerns, this article will limit its concentration to issues related to the commission's understanding of religion that prompts it to call for the regulation of religion in South Africa. It belongs to another study to provide a detailed engagement with the grave concerns raised in the commission's report.

\section{The reception of the CRL Rights Commission's report}

It must be noted that the 2017 CRL Rights Commission's final report was a watered-down version of the preliminary report issued in 2016, which contained drastic proposals. For example, Section 18.1 proposed the drafting of a new parliamentary act to set some criteria for a religion to qualify as a religion; one of the proposals was that no religion be accredited if it had practices deemed to have a harmful effect on the physical or mental well-being of its followers or if deemed exploitive of those practising it. This recommendation, which is left out in the 2017 final report, would have seriously shaken the South African religious landscape.

Some writers have welcomed the CRL Rights Commission's call for the regulation of religion in South Africa. Maviya (2018) lauds the commission's recommendations as a commendable attempt to grapple with the sensitivity of religion and social well-being. Maviya (2018), however, finds that the commission's recommendations do not really address the root of the problem, lying in 'unregulated, personality driven Christian and traditional practices'. That is, while the commission's recommendations address issues such as sexual violations and financial misconduct, they do not address the psychological and spiritual power on which religious leaders thrive. Consequently, Maviya (2018) sees a need to protect 'the core values of dignity, equality and freedom' because it is not enough to just uphold the constitution as proposed by the CRL Rights Commission. For Maviya (2018), the commission should form an investigative unit 'to investigate religious practices that may not amount to a crime but nevertheless have the effect of objectively harming church members'. Ultimately this calls for the scrutiny of all the doctrines and practices of the church to see if they cause any harm to the members. To Maviya (2018), while religion is a sensitive and private issue to many people, 'its practice is public and must be regulated'. However, while justifiable, the view of religion presented by Maviya, just like that held by the CRL Rights Commission, is a purely humanistic and legal one, where undesirable elements can simply be discussed and discarded upon their condemnation. However, in reality many religious people view themselves as not just adherents of easily negotiable and easily discarded laws and practices but as under obligation to obey at all cost the transcendent ultimate being. Therefore, what may seem abusive and humiliating in the present may be considered beneficial from a transcendent, spiritual and eschatological perspective; for instance, some may impoverish themselves by giving all their material possessions to the church in the hope for a better reward in heaven.

Mokhoathi and Rembe (2017:7) find that the CRL Rights Commission conducted its investigations, poorly showing 
that it is unable to effectively address human rights abuse by religions in South Africa. As a result, Mokhoathi and Rembe (2017:7) say, 'the State must find a way to intervene in matters that involve the violation of human rights and human dignity by religious institutions'. These authors' call for the state to intervene suggests that they do not view the CRL Rights Commission as an organ of the state, when in fact the commission describes itself as a state institution (CRL Rights Commission 2017:7). Contrary to Mokhoathi and Rembe's view, Coertzen (2017:20) says the work of the commission is ultimately the work of the state. Nonetheless, Mokhoathi and Rembe justifiably hold the conviction that religion should be regulated in South Africa because Pentecostal and Charismatic churches grossly violate the human rights of their congregants.

Similar to Maviya's noted concern that the CRL Rights Commission's recommendations do not directly deal with the root causes of the violations of human rights in religions, Mokhoathi and Rembe (2017:3) find that the South African constitution does not give a proper clarification of the reservations or limitations of religious liberties'. The authors are concerned that Section 15.1 of the South African constitution merely defines religious liberties as 'the right to freedom of conscience, religion, thought, belief and opinion' (Mokhoathi \& Rembe 2017:3) without spelling out what ought to happen when these provisions infringe on human rights. These authors and others like them base the arguments for the regulation of religion in South Africa on the constitutional protection of human rights. There is merit in these authors' arguments. However, it is noted that the reported abuses of congregants in Pentecostal and Charismatic churches emanate from religious dogmas, spiritual and prophetic revelations (CRL Rights Commission 2017:21), as well as certain interpretations of biblical texts and theological positions. This sets the constitution and Bible (or the community's authoritative divine texts) into collision. Maviya's (2018) argument that the CRL Rights Commission's interventions 'are not intended to stop religious practice but to protect religious practice and those who engage in it [the religion]' has hardly considered the power of the authority of the divine text that leads religious adherents to say it is better to obey God than man (Ac 5:29) or boisterously declare that the wisdom of God is foolishness to man (1 Cor 1:18). Therefore, those who accept the CRL Rights Commission's recommendation for the regulation of religion need to be reminded of many biblical examples of committed believers for whom the religious texts are more authoritative than the laws of the land (Dn 3:16-18; Ac 4:18-20). It is beyond the focus of this article to do a detailed exegesis of this biblical text, but it will simply highlight the fact that the conflict between the community of faith and state authorities has existed from time immemorial and that when such a conflict occurs, some believers, whether from a narrow view of faith or misinterpretation of scriptures, opt to disobey the state, even if it means paying the ultimate penalty. Based on texts such as 1 Peter 2:11, which describe Christians as aliens and strangers in this world, some Christians consider themselves as alternative communities, which means that any attempts to regulate them will result in their preference for martyrdom over compliance with the state.

Likewise, objectors to the commission's call for the regulation of religion base their objections on the constitution's guaranteeing of religious freedom. For instance, Coertzen (2017) argues that the constitution guarantees and protects freedom of religion in South Africa. Therefore adopting the proposals of the CRL Rights Commission 'will be unconstitutional, wrong, a serious offense against freedom of religion and a clear attempt of the state to control religions and churches in South Africa' (Coertzen 2017:22). In agreement, Pothier (2016:4) argues that while to some extent the purposes that the commission seeks to achieve by its proposals are admirable, 'it surely cannot be claimed that they (purposes) are so important as to warrant the wholesale violation of rights that would be involved'. Thus the proposals of the commission are rejected based on the premise that the constitution gives freedom of religion.

Other concerned voices see the commission's proposal to regulate religion as infringing on the freedom of worship and conscience (Badenhorst 2016; Freedom of Religion South Africa 2017). To the religious lobby group Freedom of Religion South Africa (2017), no one, including the state, has the right 'to decide which religions qualify as a "religion," or to sit as "judge" over the doctrines of religious institutions, and decide whether they can operate'. The commission's proposals are rejected on the firm belief that religious communities in South Africa have a right and freedom 'to believe, teach, preach and live out our religious convictions and beliefs, without the control and interference of the State' (Freedom of Religion South Africa 2017).

Pothier insightfully bases his rejection of the commission's recommendation on the moral wrongness of the actions of the Pentecostal and Charismatic pastors. Pothier (2016) states:

Locking people in deep freezes or driving over them are surely matters that need to be reported to the police, rather than being discussed under the guise of freedom of religion. (p. 2)

In other words, the commission has not distinguished criminality and freedom of religion. He adds:

Overall, it would have been preferable for the Commission to have brought a few test cases before the courts, rather than devoting its efforts to inventing a vast structure of control and oversight which - if it should come into being - will fail entirely to distinguish between genuine churches and those that merely masquerade as such. (Pothier 2016:2)

Thus the commission's proposals are rejected on the basis of poor distinction between genuine religion and those masquerading as truly religious. It can thus be argued that there are already laws in place to deal with the criminal elements masquerading as expressions of freedom of religion, and there is no need to make new laws. 
In summary, the various people base their acceptance or rejection of the commission's proposals on the constitution. Those who accept the commission's recommendation base it on the constitution's protection of human rights and human dignity, which they find are grossly violated by the churches. Those who reject the regulation of religion appeal to the constitution's provision of freedom of religion, while others say instead of grafting laws that will burden all religious societies the commission should identity the elements of criminality and hand them to the police.

\section{The commission's investigative study on controversial religious practices}

It is important to look at how the CRL Rights Commission conducted its investigations on the commercialisation of religion and abuse of people's belief systems. South Africa prides itself as a constitutional democracy and a multireligious society. The country's secular liberal constitution guarantees freedom to religions, allowing all religions to exist in South Africa. The constitution leaves scope for all kinds of beliefs and opinions, including views that may be regarded as extreme (CRL Rights Commission 2017:34). The commission exists to promote respect for the rights of cultural, religious and linguistic communities and to promote tolerance among religious communities because the 'right to cultural, religious, and linguistic identity is an inalienable right inextricably connected to human dignity' (CRL Rights Commission 2017:8). This promotion and protection of religious, cultural and linguistic rights is necessary for the realisation of 'the South African dream of building a nation united in diversity' (CRL Rights Commission 2017:8). In terms of the CRL Act, the task of the commission must also be to monitor, investigate and research any issue concerning the rights of cultural, religious and linguistic communities (CRL Rights Commission 2017:8).

Consequently, in response to various media reports of disturbing 'unconventional practices' (Resane 2017:1) and 'the unusual practices' (Kgatle 2017:1) in mostly Charismatic and Pentecostal churches, the commission launched an investigative study on the state of religion in South Africa. As reported in the media, the bizarre practices included pastors commanding their congregants to eat grass, snakes, hair, ants and toilet paper; drink petrol; drink detergents such as Dettol; a pastor spraying congregants with an insecticide called Doom; and another instructing congregants to lie down while he drove a car over them (Makhubu 2016). Motivating its investigation, the commission stated (CRL Rights Commission 2017):

[R]ecent controversial news reports and articles in the media about pastors instructing their congregants to eat grass, snakes, drink petrol or part with considerable sums of money to be guaranteed a miracle or blessing, have left a large portion of society questioning whether religion has become a commercial institution or commodity to enrich a few. Some communities have also started asking whether the government should leave the developments as they are or should something be done about the perceived commercialisation of religion. (p. 6)
The primary interest of the commission was establishing the extent of the commercialisation of religion and the abuse of people's religious beliefs. Announcing the launch of the investigations on 20 August 2015, the chairperson of the CRL Rights Commission, Ms Thoko Mkhwanazi-Xalavu announced:

We are launching an investigative study on the commercialisation of religion and the abuse of people's belief systems in terms of when these institutions are being run, how are they being run, where is their funding going into, who collects how much and what they do with the money, where does the money eventually go to, what are the governing principles that are there. (in Pothier 2016:1)

The 'investigative study' was conducted between 03 November 2015 and 23 March 2016 in all of South Africa's nine provinces by summoning pastors to hearings. The summons were served through the Sheriff of the Court, and the commission invoked the legal sections that empower it to charge and jail people who refuse to heed its summons to appear before it (CRL Rights Commission 2017:14, 59). The commission justified its use of subpoena by its limited budget for hearings, which meant that it could not afford a second round of meetings to address those who missed the first round.

The commission summoned 85 religious leaders, of which 68 were from the various Christian groups; the other 17 came from 9 non-Christian religions, including Judaism, African religions, Hinduism, Islam and Bahai (CRL Rights Commission 2017:53). The list was broken down as follows: 68 Christian pastors comprising 20 Charismatics (special gifts such as healing, 27 Pentecostals [Holy Spirit]), 10 from African Independent churches (AICs) and 11 from mainline churches (CRL Rights Commission 2017:53). The majority of the religious leaders who appeared before the commission were Charismatic or Pentecostal Christians. The summons required the religious leaders to bring documents that included a qualification certificate from an accredited institution, proof or certificate of ordination or anointment, religious institution registration certificate, annual financial statements from 2012 to 2014, the last 6 months of bank statements of the religious institution, Annual General Meeting (AGM) minutes from 2012 to 2014, a constitution or code of conduct, disciplinary codes, a statement of faith, signatories to the bank accounts, title deeds or lease agreement of the land they were operating from and the organogram (CRL Rights Commission 2017:59). The leaders were required to make a 25-30 minute presentation before the commission detailing the history of the religious institution; the training of religious leaders; the religious institution's governance structure; fundraising strategies; payments for services such as funerals, weddings and prayers; the utilisation of the religious institution's money; the transfer of money outside South Africa; and the employment of foreign pastors (CRL Rights Commission 2017:58). In addition, the summons stated that those appearing before the CRL Rights Commission were entitled to appear with legal representation, and it ended by spelling out the consequences of not heeding the summons, namely, that such a 'person shall be guilty of an offense and liable on 
conviction to a fine or to imprisonment for a period not exceeding one year' (CRL Rights Commission 2017:59).

As reported in the news (Abraham 2015; Cape Talk 2015; eNCA 2015; Masweneng 2017) and also acknowledged by the commission (CRL Rights Commission 2017:10), some religious leaders bitterly opposed appearing before the commission and there were chaotic scenes at the hearings as pastors and their followers registered their opposition and disdain of the commission. The commission reported that the commissioners were constantly insulted, threated with death and in some instances the chairperson of the commission was labelled a devil worshipper, a satanist, and the devil's girlfriend (CRL Rights Commission 2017:18). The report records that some pastors demonstrated their resistance to the commission by refusing to take the prescribed oath, refusing to submit the required documents and many other dramatic scenes (CRL Rights Commission 2017:17). The followers taunted the commission while chanting praises to their pastors, such as 'my father, my father, my father' and 'my bishop', while some supporters wore black T-shirts inscribed, 'I am who God says I am' (CRL Rights Commission 2017:18). On some occasions the commissioners had to flee from being manhandled.

The CRL Rights Commission (2017:51) interpreted the religious leaders' resistance to the commission as giving 'the impression that they are above the law and that no process would affect them. They would simply contravene any legal framework put in place'. This interpretation is difficult to rule out because some Christian leaders do indeed believe they are above all human laws and are only accountable to God (Gunda \& Machingura 2013:21; Rukwati 2012). Furthermore, to call the chairperson of the CRL Rights Commission a devil worshipper, a satanist, and the devil's girlfriend is totally unacceptable. However, the resistance to the commission and the demonising of the commission's chairperson suggest that the religious leaders might have been manipulating the situation to appear as victims of the commission's evil machinations. On the other hand, it reflects the high sense in which religious groups experienced and viewed the commission as antireligious. Furthermore, on the one hand calling the commissioners evil names reflects an unwillingness by the religious community to be held accountable by civil authorities, but on the other hand it was a backfiring of the method adopted by the commission. For unfortunately, the chairperson of the CRL Rights Commission, Ms Thoko Mkhwanazi-Xalavu, had earlier announced the coming of the hearings in a combative tone that agitated the religious community instead of winning its good will and cooperation (Abraham 2015; Cape Talk 2015; Mokhoathi \& Rembe 2017:7; Pothier 2016:1). The chairperson's wellmeaning statement agitated the atmosphere by seemingly accusing religious groups of commercialising and abusing religion.

In his criticism of the CRL Rights Commission's method to its investigative study, the South African parliament representing the Economic Freedom Fighters (EFF) party, Ndlozi (2018) pointed out:

The question of commercialisation is much broader and much deeper than the commission is pretending. It has not asked a dialogue with pastors or priests to share light on the matter. The commission summons them to the enquiry using subpoena to be questioned, forcing them to present their financial books as if they are possibly guilty of a crime. To what end? What law could they possibly be violating? (n.p.)

The parliamentarian points out the serious weaknesses in the CRL Rights Commission's method of conducting its investigation. Primarily, commercialisation and abuse of religion were not defined, and the method the commission used to arrive at these conclusions was not given. Moreover, rather than use dialogue the commission adopted a confrontational and accusatory approach that cast the religious leaders as lawbreakers and provoked them to in turn adopt a defensive mode. One religious leader who cooperated with the commission and provided all the required documents is highlighted complaining about being subpoenaed instead of being invited to attend the hearing and the bad impression that this created in the media by linking his religious community with religious malpractice (CRL Rights Commission 2017:2324). This highlights not just the poor and inappropriate methods of inquiry but a serious failure by the CRL Rights Commission to properly distinguish wrongdoers and right doers.

Overall, the commission acted insensitively and created wrong perceptions about all religious communities. Furthermore, painting all religious communities with the same brush reinforces fears of religious persecution among religious people. The faithful ordinary members saw the commission's hearings as designed to persecute and embarrass their leaders as lawbreakers. Consequently, according to the analysis of Ndlozi (2018):

How we enter into dialogue about these problems cannot be through the power of the subpoena and investigations by governments or estate bodies. The current commission's investigation is violating religious freedoms of people and it does not even have the tools to engage them in terms of their faith. (n.p.)

\section{The findings of the commission on the state of religion in South Africa}

As detailed in the commission's final report, the commission's investigative study found as true the allegations of commercialising religion and abusing people's belief systems against several religious institutions. The following is a rundown of the 12-point summary of the findings of the commission's investigative study (CRL Rights Commission 2017):

1. There is evidence of commercialisation of religion in South Africa. The evidence includes spiritual leaders demanding substantial amounts of money from their congregants before praying for them and blessing them, the selling of water and oil to congregants at exorbitant prices, spiritual leaders demanding people to pay money before they can see them and churches that have set up 
bank speed points for people to swipe their bank cards during church services.

2. Religious institutions are not complying with existing appropriate laws of the land as reflected by noncompliance to various stipulated registration requirements, including non-compliance with the tax laws of the country.

3. Some religious institutions are operating without good governance structures such as codes of conduct, church councils and disciplinary committees. In some cases, there were churches controlled and owned by one person, finance committees constituted of the spiritual leader, his wife and close associates, and a lack of leadership succession plans.

4. There is misuse of visa application systems by religious leaders. According to the report, some pastors apply for a different type of visa, like a visitor's visa or temporary visa, but then demand a permanent or residence visa once in the country.

5. There is flouting of banking rules including the nonbanking of offerings collected from the congregants in commercial banks. In some cases, the church leader acts as the treasurer and deposits the money into his own account. The report decries the lack of structure of financial control.

6. Some churches evade paying tax, as some churches are registered as non-profit organisations (NPOs) but have an annual turnover beyond the NPO limit and do not declare that to the South African Revenue Services.

7. There is uncontrolled movement of cash in and out of the country without the approval of the South African Reserve Bank. In some churches members are instructed to deposit their offerings to the churches' headquarters, located outside South Africa.

8. Churches in South Africa have mushroomed because it is easier to establish churches in the country than in other African countries.

9. There is illegal and unethical advertising of religious and traditional healing services and the proliferation of various forms of advertisements promising people solutions to their problems.

10. Properties bought with congregants' contributions have been registered in spiritual leaders' names, which has translated into building family empires with public money.

11. Religious institutions have been operated as a business. The report notes the lack of clear separation between religious activity and business activity in the religious institutions.

12. There is a lack of religious peer-review mechanisms in the religious sector, allowing spiritual leaders to do as they please because there is no system of accountability, leading to occurrences of pastors commanding their congregants to eat grass, snakes, rats, drink petrol and putting congregants in deep freezers. (pp. 31-33)

The 12-point summary shows that there is commercialisation of religion and abuse of people's belief systems. According to the findings of the commission, churches violate the constitutional rights of congregants and break the laws of the country (CRL Rights Commission 2017:34). Churches are not exercising their religious freedom with due regard to their legal, ethical and community responsibilities (CRL Rights Commission 2017:34). In many ways, the CRL Rights Commission is concerned about balancing religious freedom and adhering to the constitution and the various laws of the republic. That is, religious communities must not exercise their religious freedom in a way that negates legal, ethical and community responsibilities. The summary shows that there are serious ethical problems among churches in South Africa, both in regards to the human rights and dignity of the congregants, financial integrity and adherence to the laws of the country.

However, a serious critique of the report is that it does not detail the extent of the identified problems among the churches. There is no indication of statistical data of how many of the sampled churches were evading paying tax and how many foreign pastors had misused the visa system. Furthermore, the commission describes as a misuse of the visa application when a pastor applies for a change of visa, and yet the immigration laws of South Africa do allow for foreigners with justifiable cause to apply for a change of conditions on their visas. Furthermore, it is unclear if the commission's concern about the mushrooming of churches in South Africa is a concern about mushrooming of foreign-led churches or the general increase of churches. Furthermore, the report does not link the increase of foreign pastors with the increase of the immigrant population in South Africa. However, raising the alarm about the general increase of churches in the country ultimately questions the essence of freedom of religion, which allows people to propagate their faith and as a result build more churches. Specifically directed to Christians the central message of the commission's report indicted churches for failing to live up to their witness, for not being the salt and light of the world, and ultimately condemned them for being poor witnesses of Christ their Lord. All true Christian believers must therefore be concerned about high levels of duplicity among them.

\section{The recommendations of the commission}

In the light of the above findings, the CRL Rights Commission recommends the regulation of religion in South Africa. The commission stated, 'The investigative study highlighted the need to protect religious freedom without attempting to regulate it from the side of the State' (CRL Rights Commission 2017:34). Specifically, the commission recommended religious organisations to adopt self-regulation. However, the recommended self-regulation requires the amendment of the CRL Act legislation (CRL Rights Commission 2017:39). The commission stated that the amendment:

[W]ill assist institutions to create an environment where they, and not the State, can effectively regulate themselves, and hold people who bring religion into disrepute accountable, as per their various religious systems. (CRL Rights Commission 2017:39) 
Therefore the commission recommended 'a process that will establish a mechanism for registering religious leaders' places of worship and umbrella organisations through the recommendations of umbrella bodies on behalf of their constituencies' (CRL Rights Commission 2017:39).

The nature of the recommended registration mechanism for religious leaders is similar to that of other professional bodies such as those of lawyers, nurses, doctors and engineers (CRL Rights Commission 2017:39). The commission believes 'this registration mechanism will also help to professionalise the religious sector further, without compromising the internal requirements of various institutions for recognising those of a religious leader' (CRL Rights Commission 2017:39). In essence, the commission proposes to be the final arbiter in religious matters.

It is noted that the commission's proposals impose a particular professionalisation of ministry on the churches, thus dictating to Christians how they should run their churches. The proposals ultimately redefine the Christian religion by imposing a view of Christian ministry that is a secular view of professionalism, which may not be in line with Christian ideas of ministry. The CRL Rights Commission proposes the formation of accredited 'umbrella organisations or associations' and recommends that all religious institutions be required to fall under an umbrella organisation of their choice in accordance to their religious beliefs (CRL Rights Commission 2017:39). The commission further proposes that above the umbrella organisations be set peer-review committees, which will ensure that there is 'religious selfregulation and accountability' (CRL Rights Commission 2017:47). The CRL Rights Commission says instead of the state or government, the commission will be the one that holds the final authority and issues registration certificates to religious practitioners in consultation with the peer-review committees of umbrella bodies of each religious organisation. The commission states,

[T] he registration of a religious institution to operate or not would be determined by the relevant Peer-Review Committee members, who will then advise the CRL Rights Commission of the newly registered entities. (CRL Rights Commission 2017:39)

This means that all religious communities have to belong to an umbrella body, which must register them in order for them to be recognised as a bona fide religious community in South Africa. However, as Coertzen (2017:16) states in his analysis, while the CRL Rights Commission attempts to create a distinction between itself and the state, its existence is in terms of the constitution so how can it not be the state, or a representation of the state at the least? The important point raised by Coertzen is that although the commission is an independent point, it is ultimately established by the state (Bizcommunity 2018; CRL Rights Commission 2017:7). Another problem is that, while the CRL Rights Commission says the proposed structural arrangements will ensure freedom of religion, if it is the one that issues the certificate for a religion to operate this means that it has the power to revoke that certificate (Coertzen 2017:16). This means that ultimately the state will control religion in South Africa and thus take away the freedom of religion.

\section{The problems with the CRL Rights Commission's understanding of religion in South Africa}

In light of the preceding discussions of the CRL Rights Commission's approach to religious matters and its passionate recommendations for the regulation of religion in South Africa, what is reflected about the commission's understanding of religion in the country? This section specifically answers the main question of the article by highlighting some issues that emerge from the previously discussed points, which provides some indications of the commission's understanding of religion in South Africa.

\section{The commission's unbalanced portrayal of religion as a danger to society}

The commission's report overly presents religion in South Africa as a serious danger to the well-being of society that needs to be seriously monitored. Indeed, the incidences of pastors feeding people grass, snakes, rats, drinking petrol, locking people in the deep freezer, driving over people and the cases of pastors convicted of raping congregants is undeniable evidence that there are very dangerous church leaders who should not be allowed to lead churches. Further, history shows that ever since the arrival of Christianity in South Africa religion has at many times played a harmful role in society as demonstrated by the church's active role in the creation of apartheid and dispossessing black people of their land (Lephakga 2013:281-282). History shows that the nations of the world, including well-developed countries like the USA, have faced outbreaks of dangerous religious movements that have even resulted in the mass deaths of innocent people. This shows that there are many dangerous people using the cover of religion to harm people. However, right before the start of the church, Christ warned believers to be careful of ravenous wolves who come in sheep's clothing (Mt 7:15-17). While time does not allow for full exegesis on these passages, it can be stated that these things are pointed out in the scriptures as warnings to believers to be alert to those who use religion to harm others in order to preserve the integrity of religion.

Although the commission's study was motivated by reports of abuse of religion and focused on establishing the extent of the problem, the report uncritically and unfairly portrays the whole religious landscape in South Africa as so rotten to the core that it needs the urgent intervention of the state. Moreover, the commission's report is silent on the efforts of many pastors and religious leaders who faithfully watch over their flocks and diligently and fervently warn their congregants to be careful of religious impostors. Furthermore, the commission's report is silent on the work of many church bodies that diligently condemn impostors and dangerous 
doctrines. The commission unfairly sets itself as the saviour of the church and ignores the large volumes of work done by many church leaders, academics, theologians and scholars to preserve the integrity of the church and the gospel.

The commission's unbalanced portrayal of religion as a danger to society overlooks the fact that 'every week millions of South Africans routinely attend religious services and play their part in their churches'/mosques'/temples' activities without being in any way exploited or duped' (Pothier 2016:2). It can also be pointed out that public expression of religion such as prayer meetings in workplaces and open worship services held while people are riding on public trains to work is evidence that many South Africans find religion useful to their lives. The commission's desire to have control over religious institutions is insensitive to the function of religion as a survival strategy for the poor. While there are indeed abusive churches, there are also many South African churches that function as fountains of human flourishing, promote the well-being of the poor and protect the marginalised and the abused in society. The report fails to capture the fact that many vulnerable South Africans trust their religious institutions to protect them and empower them to overcome their various social and personal problems.

\section{A view of religion not informed by past and ongoing research on religion}

The understanding of religion portrayed in the CRL Rights Commission's report and recommendations does not seem well informed by the large volume of past and ongoing research on the problem of commercialisation of religion and abuse of people's belief systems (Asamoah-Gyadu 2009; Bowman 2001; Gifford 2004; Harrell 1975; Horn 1989; Marshall 2009; Maxwell \& Phiri 2007; Ojo 2008). A consultation of past and ongoing research on commercialisation and abuse of religion by local and international scholars would have enlightened the commission on how religious leaders who are daily confronted by the harmful effects of religious impostors are addressing these problems as well as how they are equipping and empowering their congregants to stay safe.

Furthermore, neither the report nor the recommendation of the commission reflects a meaningful consultation, dialogue or input from South Africa's large ecclesiastical bodies, like the Southern African Catholic Bishops' Conference; ecumenical bodies such as the South African Council of Churches and the Evangelical Alliance of South Africa; or professional Christian bodies such as the Theological Society of South Africa and the Society for Practical Theology in South Africa, just to name a few. Essentially, the commission seems to have disregarded the collaborative work by various academics, theologians, legal scholars and religious leaders who formulated the South African Charter of Religious Rights and Freedoms to explain the meaning of freedom of religion to all South Africans. If the commission did consult any of these bodies, that input is difficult to see in its recommendations.

Furthermore, the commission's recommendations do not seem informed by how some African countries have dealt with similar problems. For instance, Zimbabwe has struggled with some sections of the African Independent Churches (AICs), who deny their children education and immunisation, teach against hospital medicine and also practise child marriage and forced marriage. The government, with the assistance of various organisations, has confronted these churches to challenge them on harmful cultural practices such as polygamy, child marriage and denying women and children rights and access to medication (Vengeyi 2013:72). Some members of these churches have been jailed for abusing their children and wives (Vengeyi 2013:73). The various governmentengagements and dialogues with these groups have yielded fruit, although very marginal. The fact that some members of these churches now campaign within their churches against the harmful and oppressive religious beliefs that violate the rights and dignity of children and women shows that the engagement by the government and civil society is bearing fruit, no matter how small. Rather than regulate these AICs, which may lead them to go into defence mode or operate underground, they have been engaged and challenged to abandon their dangerous and oppressive religious beliefs and practices. The problems raised by the CRL Rights Commission are not unique to South Africa; there is therefore a need to learn how other countries are dealing with them.

\section{A secularistic perspective that undermines the otherworldliness of religion}

The CRL Rights Commission's recommendations for the regulation of religion reflect a secular humanistic view of religion by only promoting the constitution and secular views as the basis for churches to reform their way of doing things. The commission wants a professionalisation of Christian ministry along the models used in secular professions, which insist on professional training and academic qualification. While this may be helpful in enhancing efficiency and order in churches, it overlooks the common understanding of Christian ministry as a spiritual vocation, driven by the call of God and empowered by the Holy Spirit. While professional qualifications are needed and useful, the CRL Rights Commission's insistence for one to register as a minister of religion overlooks the suspicion of many Christians towards the academy. As an example, Zimbabwe's Prophet Walter Magaya (2015) says critical theology has misled pastors and churches and vows that he will not advise anyone to go to a Bible or theological school, because ' $[w]$ rong theories of God's Kingdom are being reinforced in the minds of many people through those colleges'. Many churches emphasise spiritual capacity because they believe ministry is fundamentally a divine calling that comes with miraculous spiritual capacitation for ministry. Other churches find no value in theological training because they believe a person is called and equipped miraculously for ministry. This article fully believes that churches should critically rethink their one-sided emphasis on spirituality and value critical theological training.

Furthermore, the CRL Rights Commission's secularistic critique of ministry does not appropriately deal with the 
antiworldly character of many religions. For instance, many Christians believe that giving to the pastor is giving to God and also believe that one can sacrificially give up all their possessions for the sake of the gospel as an investment into one's eternal life. Some Christians want to emulate the biblical examples of those who gave up all their wealth for the sake of following Christ. Indeed, while such sacrificial acts may not be the right action for all Christians, the question is what instrument will the CRL Rights Commission use to condemn or discourage it? Therefore, there is a need to understand that what may appear as a violation of human rights cannot just be adequately critiqued from a perspective of the law or the constitution without critiquing the operational theological framework.

The CRL Rights Commission's belief that proper leadership training and a leadership succession plan will prevent schisms may be true, but other historical events contradict it. Just like in politics and other social spheres the presence of a succession plan does not always stop the occurrence of schisms after the death of the leader of an organisation. The commission is being presumptuous to believe that leadership succession structures will prevent religious schisms and secessions. From a Christian theological perspective such notions are inattentive to the fallenness of humanity.

The secularist perspective that undermines the spiritual nature of religion also lacks awareness of the dynamic nature of religion. The commission's alarm over the mushrooming of churches in South Africa is unfortunately made without the awareness that South Africa has not only been the hub of Christianity in Southern Africa but also a launching pad for Christian missions ever since the arrival of Christianity in this part of the continent. Moreover, like elsewhere in the world, the influx of refugees and migrants in to South Africa will naturally also result in many foreign-led churches. Furthermore, the commission needs to understand that Christianity is a dynamic organism, and therefore growth through more conversions and the building of churches is in its nature.

\section{Inattentiveness to the quest for religious freedom by Christians in South Africa}

The CRL Rights Commission's recommendation for a 'vast structure of control and oversight' (Pothier 2016:2) of religion reflects an understanding of religion that is inattentive to the quest for religious freedom by many ordinary South African Christians. The quest for religious freedom in South Africa is illustrated in the origins of the AIC. Masondo (2014:2) says, 'The African indigenous churches exemplify the African struggle for self-identification and self-realisation'. In colonial times this quest for self-identification and self-realisation included freedom from white control, freedom from white missionary paternalism and the quest to worship God in accordance to one's perceived encounter with God. The initial AIC leaders broke away from established churches to express their religious freedom. Indeed, while some of their beliefs may be deemed unorthodox and controversial, these cannot be addressed by forcing them into hierarchical authority as proposed by the CRL Right Commission. However, various theological departments in some South African universities run programmes targeting AICs to equip them with biblical literacy skills to empower them to exercise their religious freedom informatively.

\section{Undermining the uniqueness of churches and denomination}

The hierarchical structure for regulating religious institutions proposed by the CRL Rights Commission undermines the uniqueness of the churches. Coertzen (2017:20) rightly points out that the proposed structure is a blatant attempt by the state through the CRL Rights Commission to prescribe to religions what organisational structure they should adopt. And yet, 'freedom of religion means that religions have the freedom to determine their own organisational and doctrinal structures and they do this in terms of their faith identity' (Coertzen 2017:20). Coertzen (2017:20-22) provides a lengthy list identifying differences among Christians to show that the organisational structure proposed by the CRL Rights Commission is potentially dangerous. While some churches have promoted ecumenicity by promoting the unity of all churches, other churches view ecumenicity as a threat to the purity of the church and argue that preserving the purity of the church demands that each church stand alone and be accountable to Christ only. The CRL Rights Commission's insistence on the registration of all churches is not alert to the many Christians who do not believe in highly formalised churches, who worship in open spaces, along the rivers, on mountains and even in private homes. Many emerging free and house churches and numerous AICs either have a simple or no formal structure at all. Many prophetic churches that are dependent on the prophetic calling of their leaders may not believe in joining large ecumenical bodies. If the CRL Rights Commission's proposals become law, it means many Christians who exist as independents will not be able to practise their faith as guaranteed in the South African constitution. A serious problem is that the CRL Rights Commission seems to either poorly engage various church governing bodies that deal with divergences in denominations or to totally surpass these governing bodies in authority.

In summary, the section has argued that the CRL Rights Commission's understanding of religion in South Africa, especially Christianity, is not sufficiently informed by the positive developments within the churches. The commission's report expresses a negatively unbalanced view of churches, which hinders a meaningful engagement with the churches.

\section{The problems of regulating religion}

A further question that emerges is as follows: In a South African context riddled with high economic inequality and powerlessness, where many poor and powerless people rely on religion as a means of engaging their socio-economic and political reality, what would be the implications of regulating religion? 


\section{Regulating religion as disempowering the poor and the powerlessness}

The article contends that in a context riddled with high economic inequality and powerlessness, religion is a powerful tool for the poor and powerless. The high levels of poverty, corruption, crime and violence, high costs of living and medical care and poor service delivery mean that many poor people turn to religion as a strategy of survival and existence. It is beyond dispute that religion can, and indeed often does, play a disempowering, impoverishing and oppressive role in society. The noted unconventional and dehumanising occurrences in some Pentecostal and Charismatic churches prove the point. However, a fair assessment of the role of religion in society cannot overlook its empowering role. While alert to the negative role of religion, Agbiji and Swart (2015:10) point out: 'Religion creates hope and optimism in spite of failed governments and economic institutions in Africa'. Religion points people to the reality and power of God, calling them to trust God to transform their impossibilities. Agbiji and Swart (2015) add:

Alongside the building of optimism in the lives of worshippers through the hermeneutics for conscientisation, religion also contributes towards conscientising the religious practitioner to be responsive to the challenges of society. As a result, the religious person becomes a source of social capital. (p. 11)

Therefore, to take away or tamper with the freedom of religion of ordinary people and place it in hierarchical bodies is to rob the poor of their only power to transcend their circumstances.

\section{Creating conditions for religious persecution}

Regulating religion in the manner proposed by the CRL Rights Commission will create conditions for the persecution of religions. The Mail and Guardian newspaper reporter de Wet (2017) quoted the commission's chairperson, Thoko Mkhwanazi-Xaluva, as saying the commission's:

[P]oint of departure is that, as a pastor, you must be licensed; we must register you, so that when your elders say 'you are no longer fit to be one of us', then we can say we are revoking your licence, you can't preach here anymore, go find another job somewhere. (n.p.)

The question is: will a pastor who genuinely believes that he has been called by God to preach the gospel stop preaching just because the CRL Rights Commission has taken his licence to preach? Furthermore, will aspiring preachers who are convicted of their calling patiently wait for the licencing bureaucratic procedures to finish before they can fulfil their callings? The commission's ambitions are not informed by the many examples in the Bible where prophets and disciples disobeyed the orders of the authorities to not prophesy and preach and continued with their ministerial works even when it meant being killed. The CRL Rights Commission's recommendations will create conditions for the persecution of religious people.

\section{Forcing religious movements to operate underground}

Regulating religions has the potential to force religions to operate underground if for some reason their registration is not approved. The refusal by colonial authorities to recognise African traditional religious ceremonies did not make Africans abandon their religious practices. They in fact conducted them at night under the cover of darkness (Adamo 2011:1). Furthermore, the enactment of the Witchcraft Suppression Act in colonial times did not eradicate the African belief in witchcraft. It is observed that in countries where religious activities are restricted or outlawed, religious movements continue to operate underground with great success. In view of the ordinary people's reliance on religion, restricting religion will force religious movements to operate underground, which will increase the vulnerability of many people. In a religion that operates underground or as a secret society, the vulnerability of the members is greater by heightening dependency of the followers on a spiritual authority that is beyond public scrutiny. Furthermore, a religion that operates underground carries many chances of driving its members into a form of spiritual desperation that fosters an absolute dependency on the spiritual leader.

\section{Conclusion}

The article attempted to wrestle with the following question: what do the recommendations of the CRL Rights Commission to regulate religion in South Africa reflect about the commission's understanding of religion in the country? From the preceding discussion, it is noted that the CRL Rights Commission's understanding of religion and its approach to the controversial bizarre practices by churches is heavily secularistic (Ndlozi 2018) and humanistic, resulting in poor engagement with religious institutions. As indicated, churches should not dismiss the commission's 2018 report but should engage it in the light of Christ's call to his followers to be the light and salt in the world. It is the task of another study to deal with the positive aspects of the report and to also show that, at the end of the day, the report calls to churches for a higher morality that is already found in the scriptures.

This article has attempted to identify the dangers of the recommendations by the CRL Rights Commission that religion should be regulated in South Africa. The article finds that, as articulated by the commission, there is no difference between self-regulation and state regulation because the CRL Rights Commission will have the final authority and be the licencing authority of all pastors as well as the registering authority of the worship centres. The article concludes that religious communities must resist the commission's efforts to regulate religion because its secular humanistic understanding of religion attempts to redefine religion in ways that are unhelpful to religious communities. However, rather than be hostile, religious communities must graciously challenge the CRL Rights Commission to protect the freedom of religion by working with religious communities to distinguish authentic religious practitioners from religious impostors who should 
be reported to the police and face the wrath of justice. Coertzen (2017) rightly points out that it is

$[\mathrm{N}]$ ecessary that people, churches and religions must take responsibility to protect their freedom of religion. If they don't do that the State and its organs will take over and define the boundaries of religion. (p. 23)

\section{Acknowledgements Competing interests}

The author declares that he has no financial or personal relationships that may have inappropriately influenced him in writing this article.

\section{Authors' contributions}

C.B. is the sole author of this article.

\section{Funding information}

This article is part of the author's postdoctoral project at North-West University.

\section{References}

Abraham, V., 2015, CRL commission must fall - Bishop Zondo, viewed 13 June 2017 from http://citizen.co.za/news/news-national/853475/crl-commission-must-fallbishop-zondo/.

Adamo, D.T., 2011, 'Christianity and the African traditional religion(s): The postcolonial round of engagement', Verbum et Ecclesia 32(1), Art. \#285, 10 pages. https://doi. org/10.4102/ve.v32i1.285

Agbiji, O.M. \& Swart, I., 2015, 'Religion and social transformation in Africa: A critical and appreciative perspective', Scriptura 114(1), 1-20. https://doi. org/10.7833/114-0-1115

Asamoah-Gyadu, J.K., 2009, 'Did Jesus wear designer robes? The gospel preached in Africa's new Pentecostal churches ends up leaving the poor more impoverished than ever', Christianity Today 53(11), 38-41.

Badenhorst, N., 2016, CRL Commission moves quickly to regulate religion in South Africa, viewed 11 June 2017, from https://forsa.org.za/crl-commission-movesquickly-to-regulate-religion-in-south-africa/.

Bizcommunity, 2018, Nominations open for commissioners of the CRL Rights Commission, viewed 15 January 2019, from https://www.bizcommunity.com/ Commission, viewed 15 Janu
Article/196/546/180369.html.

Bowman, R.M., 2001, The word-faith controversy: Understanding the health and wealth gospel, Baker, Grand Rapids, MI.

Browning, M., 2013, 'A tribute to Chirevo Kwenda', viewed 19 July 2017, from http:// www.a-asr.org/a-tribute-to-chirevo-kwenda.

Cape Talk, 2015, 'I feel my life is seriously under threat' - CRL commission head, viewed 13 June 2017, from http://www.capetalk.co.za/articles/6478/crlcommision-threats.

Coertzen, P., 2017, 'Freedom of religion: To have and to protect religious rights and freedoms', paper, Stellenbosch University.

Collison, C., 2017, Hope for victims of botched circumcisions, viewed 15 January 2019 from https://mg.co.za/article/2017-11-23-00-hope-for-victims-of-botchedfrom hircumcisions/.

CRL Rights Commission, 2016, CRL Rights Commission's preliminary report of the hearings on commercialisation of religion and abuse of people's belief systems, viewed 11 June 2017, from http://www.crlcommission.org.za/docs/Preliminary $\% 20$ Report $\% 20$ of $\% 20$ the $\% 20$ hearings $\% 20$ on $\% 20$ Commercialization $\% 20$ of $\% 20$ Religion $\% 20$ and $\% 20$ abuse $\% 20$ of $\% 20$ people's $\% 20$ belief $\% 20$ systems.pdf.

CRL Rights Commission, 2017, Report on the hearings on the commercialisation of religion and abuse of people's beliefs systems, viewed 16 May 2018, from http:// www.crlcommission.org.za/docs/Report $\% 200$ n $\% 20$ Commecialization $\% 20$ of $\% 20$ Religion $\% 20$ and $\% 20$ Abuse $\% 20$ of $\% 2$ People's $\% 20$ Believe $\% 20$ Systems $\% 20$ final.pdf.
Daniel, R., 2018, Sexual abuse at religious institutions more rife than you think - CRL, viewed 15 January 2019, from https://www.news24.com/SouthAfrica/News/ sexual-abuse-at-religious-institutions-more-rife-than-you-think-crl-20180405.

De Wet, P., 2017, Christians close to 'regulation by reputation' for pastors, viewed 24 October 2018, from https://mg.co.za/article/2017-06-06-00-christians-closeto-regulation-by-reputation-for-pastors/.

eNCA, 2015, Pastor charged for refusing to face commission, viewed 13 June 2017, from http://www.enca.com/south-africa/pastor-charged-refusing-face-commission.

Freedom of Religion South Africa, 2017, CRL Rights Commission: Keep religion free from regulation in South Africa, viewed 11 June 2017, from https://www.change. $\mathrm{org} / \mathrm{p} / \mathrm{crl}$-rights-commission-keep-religion-free-from-regulation-in-south-africa.

Gifford, P., 2004, Ghana's New Christianity: Pentecostalism in a Globalising African Economy, C. Hurst, London.

Gunda, M.R. \& Machingura, F., 2013, 'The "Man of God": Understanding biblical influence on contemporary mega- church prophets in Zimbabwe', in E. Chitando, M. Gunda \& J. Kügler (eds.), Prophets, profits and the Bible in Zimbabwe: Festschrift for Aynos Masotcha Moyo, pp. 15-28, University of Bamberg, Bamberg.

Harrell, D.E., 1975, All things are possible: The healing \& charismatic revivals in modern America, Indiana University, Bloomington, IN.

Horn, J.N., 1989, From rags to riches: An analysis of the Faith Movement and its relation to the Classical Pentecostal Movement, University of South Africa, Pretoria.

Kgatle, M.S., 2017, 'The unusual practices within some Neo-Pentecostal churches in South Africa: Reflections and recommendations', HTS Teologiese Studies/ Theological Studies 73(3), a4656. https://doi.org/10.4102/hts.v73i3.4656

Lephakga, T., 2013, 'The history of theologised politics of South Africa, the 1913 Land Act and its impact on the flight from the black self', Studia Historiae Ecclesiasticae 39(2), 379-400.

Mabuza, E., 2018, Extremist church was identified by CRL in its report last year, viewed 15 January 2019, from https://www.sowetanlive.co.za/news/south-africa/201802-26-extremist-church-was-identified-by-crl-in-its-report-last-year/.

Magaya, W., 2015, Teaching on the kingdom of God, viewed 28 January 2018, from http://magaya.hurukuros.com/2015/11/teaching-on-kingdom-by-prophetmagaya.html.

Makhubu, N., 2016, The Prophet of Doom and other preachers who prey, viewed 18 July 2017, from http://www.iol.co.za/news/south-africa/gauteng/the-prophet-ofdoom-and-other-preachers-who-prey-7291771.

Marshall, R., 2009, Political spiritualties: The Pentecostal revolution in Nigeria, University of Chicago, Chicago, IL.

Masondo, S.T., 2014, 'The African indigenous churches' spiritual resources for democracy and social cohesion', Verbum et Ecclesia 35(3), Art. \#1341, 8 pages. https://doi.org/10.4102/ve.v35i3.1341

Masweneng, K., 2017, Mboro slams CRL rights commission for criticising pastors, viewed 13 June 2017, from http://www.timeslive.co.za/local/2017/01/23/ Mboro-slams-CRL-rights-commission-for-criticising-pastors1.

Maviya, L., 2018, The case for regulating religion, viewed 24 October 2018, from https://mg.co.za/article/2018-03-29-00-the-case-for-regulating-religion/.

Maxwell, J. \& Phiri, I., 2007, 'Gospel riches: Africa's rapid embrace of prosperity Pentecostalism provokes concern and hope', Christianity Today 51(7), 22-29.

Mbiti, J.S., 1969, African religions and philosophy, Heinemann, London.

Mokhoathi, J. \& Rembe, N.S., 2017, 'Religious liberties and the constitution of South Africa: A call for religious accountability', Scriptura 116(1), 1-10. https://doi org/10.7833/116-1-1145

Ndlozi, M., 2018, The trial: The church on the cross, viewed 21 October 2018, from http://firstthing.dailymaverick.co.za/article?id=73319\#.W8zHUEszZpl.

Nyathi, P., 2001, Traditional ceremonies of Amandebele, Mambo, Gweru.

Ojo, M.A., 2008, 'Transitional religious networks and indigenous Pentecostal missionary enterprises in the West African coastal region', in A. Adogame, R. Gerloff \& K. Hock (eds.), Christianity in Africa and the African diaspora: The appropriation of a scattered heritage, pp. 167-179, Continuum International, London.

Pothier, M., 2016, Regulating religion, viewed 18 October 2018, from http://www. cplo.org.za/wp-content/uploads/2016/02/BP-418-Regulating-ReligionNovember-2016.pdf.

Resane, K.T., 2017, “'And they shall make you eat grass like oxen" (Daniel 4:24) Reflections on recent practices in some New Charismatic Churches', Pharos Journal of Theology 98, 1-17.

Rukwati, T., 2012, Prophets mustn't be questioned, viewed 17 March 2017, from http://www.herald.co.zw/prophets-mustnt-be-questioned/.

SA Constitution, 1996, The constitution of the Republic of South Africa, viewed 08 June 2017, from http://www.justice.gov.za/legislation/constitution/SAConstitution-webeng.pdf.

Vengeyi, E., 2013, 'Gender-based violence in the Johane Marange Apostolic Church in Zimbabwe', in E. Chitando \& S. Chirongoma (eds.), Justice not silence: Churches facing sexual and gender-based violence, pp. 73-76, African Sun Media, Stellenbosch. 